\title{
Comparison of dietary intakes of micro- and macronutrients in rural, suburban and urban populations in Costa Rica
}

\author{
Edmond K Kabagambe ${ }^{1}$, Ana Baylin ${ }^{1}$, Xinia Siles ${ }^{2}$ and Hannia Campos 1,2, * \\ 'Department of Nutrition, Harvard School of Public Health, Boston, MA 021 15, USA: \\ ${ }^{2}$ Instituto de Investigaciones en Salud, Universidad de Costa Rica, Costa Rica
}

\begin{abstract}
Objective: To compare, along with behavioural habits, the potential atherogenicity of diets in rural and urban areas in Costa Rica.

Design: Subjects $(n=503)$ were randomly selected from the general population in Costa Rica. A validated food-frequency questionnaire that inquired about dietary intake in the previous year was administered once to each subject. Each subject provided plasma and an adipose tissue biopsy, which were used as biomarkers for carotenoid, tocopherol and/or fatty acid intakes. Each subject also answered another questionnaire on personal profile and household characteristics.

Setting: A dietitian visited all subjects and conducted the interviews at their homes. Subjects: Adult male and female free-living rural, suburban and urban Costa Ricans without a history of physical or mental disability.

Results: Subjects in rural areas were significantly $(P<0.05)$ more active physically, earned less income and had a higher intake of dietary fibre than urban dwellers. Urban residents reported a significantly $(P<0.05)$ higher consumption of total fat, specifically unsaturated fat mostly from soyabean oil, and had higher plasma and adipose tissue tocopherol and lycopene concentrations. Interestingly, no differences in body mass index were observed.

Conclusions: These data show differences in cardiovascular disease (CVD) risk factors of rural and urban populations in Costa Rica. In rural areas, low socio-economic status and low intake of unsaturated fatty acids appear to be the prevalent CVD risk factors, while in urban areas they were low physical activity, high trans-fatty acids in the diet and adipose tissue, and low dietary fibre intake.
\end{abstract}

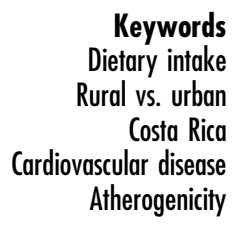

Keywords

Dietary intake

Costa Rica

Atherogenicity
In developing countries diet-related diseases are reported to be on the increase $\mathrm{e}^{1-4}$. This increase is believed to be associated with the tendency for rural populations to move to cities in search of employment. The risks attending to this urbanisation are change in eating habits and tendency towards a Western lifestyle. It is established that, in developed countries, urban dwellers generally tend to have more leisure-time physical activity and may on average consume less 'healthier' diets compared with rural populations ${ }^{5-7}$. On the contrary, limited studies in developing countries appear to indicate that, unlike urban communities, rural populations tend to be more active physically and have a lower prevalence of risk factors for cardiovascular disease $(\mathrm{CVD})^{8}$. The interaction between changes in lifestyle, dietary habits and urbanisation is of interest in designing national nutritional educational programmes and for identifying risk factors for diseases of affluence, which also tend to be more predominant among urban dwellers ${ }^{3}$. We conducted a study to describe the dietary intake of free-living Costa Rican residents with regard to their lifestyle, socio-economic status, residence and physical activity. In this paper, the dietary intakes of major nutrients and their sources are described for rural, suburban and urban populations in Costa Rica. Furthermore, the short- and long-term dietary intakes as assessed from plasma and adipose tissue biomarkers, respectively, are also documented by level of urbanisation.

\section{Subjects and methods}

\section{Area of study and subjects}

The subjects in this study were randomly selected from the greater metropolitan area of San José and the 18 neighbouring counties using census data from the National Census and Statistics Bureau of Costa Rica (Fig. 1). Subjects were visited at their homes and only those individuals without a history of myocardial infarction, stroke and physical or mental disability were recruited for this study. Ninety per cent of the subjects selected accepted to participate in this study and provided data and biological samples. Subjects were of Mestizo ethnic group (a mixture of Caucasian, Indian, Black and culturally Hispanic Americans) and were selected from a total population of $1092000^{9}$. This population lives in an area of approximately $2225 \mathrm{~km}^{2}$. The Ethics Committee of the Harvard School of Public Health and the National 


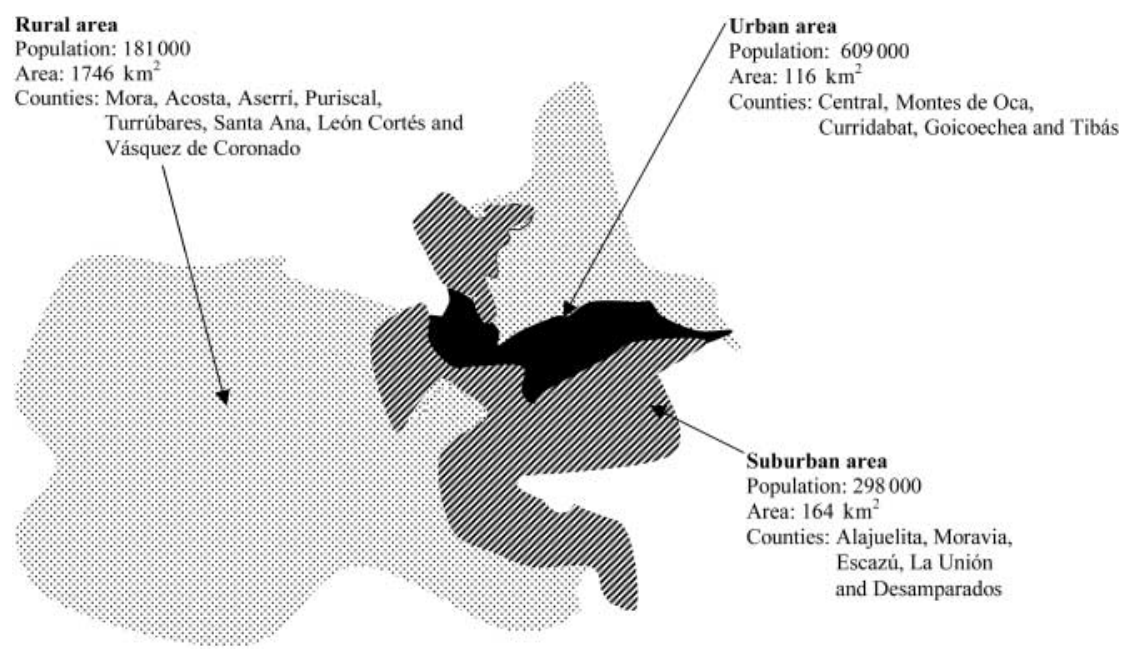

Fig. 1 Description of San José metropolitan area and adjacent counties visited in the assessment of dietary intake in Costa Rica

Institute of Health Research (INISA) at the University of Costa Rica approved all the protocols used in this study.

\section{Data collection}

Information on sociodemographic characteristics, smoking, socio-economic status and medical history, including personal history of diabetes and hypertension, was collected using a close-ended questionnaire. Self-reported data on diabetes and hypertension were validated using definitions recommended by the Expert Committee on the Diagnosis and Classification of Diabetes Mellitus ${ }^{10}$ and the Third Joint National Committee on Detection, Evaluation and Treatment of High Blood Pressure (JNCIII) ${ }^{11}$. Trained fieldworkers asked the subjects to remove their shoes and wear light clothing prior to taking anthropometric measurements.

\section{Dietary assessment}

A 135-item semi-quantitative food-frequency questionnaire (FFQ), developed by Willett et $a l^{12}$, was modified specifically to suit dietary assessment among Costa Rican inhabitants ${ }^{13}$. This instrument inquires about intakes of 135 food items which include 20 vitamins, mineral and food supplements, types of fat used for cooking and frying, consumption of fried foods in and away from home, and food habits related to meat preparation during the past year. Trained interviewers administered the FFQ to all subjects. The performance of the FFQ in Costa Rica has been further validated and found satisfactory ${ }^{14}$. The United States Department of Agriculture food composition tables were used at the Channing Laboratory to estimate total energy and nutrient intakes for each subject as described previously ${ }^{12,13}$. The subjects were asked to select only one type of fat or oil that is most frequently used for home cooking or frying.

\section{Biocbemical analyses}

All biological specimens and anthropometric measurements were taken at the subjects' homes in the morning following an overnight fast. A subcutaneous adipose tissue biopsy was collected from the upper buttock with a 16-gauge needle and disposable syringe following the procedures previously described ${ }^{15}$. Blood samples were collected in tubes containing $0.1 \%$ ethylenediamine$N, N, N^{\prime}, N^{\prime}$-tetraacetic acid. Both samples were stored in a cooler with ice packs at $4^{\circ} \mathrm{C}$ and transported to the fieldwork station within four hours. Blood was then centrifuged at $2500 \mathrm{rev} \mathrm{min}^{-1}$ for $20 \mathrm{~min}$ at $4^{\circ} \mathrm{C}$ to obtain plasma. Plasma and adipose tissue biopsies were stored at $-80^{\circ} \mathrm{C}$ and, within six months of collection, were transported over dry ice to the Harvard School of Public Health for analysis. The average yield of adipose tissue was $38 \pm 33 \mathrm{mg}$ (mean \pm standard deviation).

The concentrations of carotenoids and $\alpha$ - and $\gamma$-tocopherol were measured using a dual-wavelength Hitachi high-performance liquid chromatography (HPLC) system and data station $^{16}$. The L-4200 detector was set at a wavelength of $300 \mathrm{~nm}$ for tocopherols and at $445 \mathrm{~nm}$ for carotenoids. Injections were performed by the programmable AS-4000 Auto-Sampler. A single large sample of adipose tissue was used for between-run analytical variations. One adipose tissue aliquot from the core of the sample, with weight similar to that of most of the unknown samples (20-60 mg), was included in every run over the period of the study. Every run also included one pooled plasma sample. The coefficients of variation (CVs) for adipose tissue $\alpha$ - and $\gamma$-tocopherol were $20.4 \%$ and $17.8 \%$, and for plasma $\alpha$ - and $\gamma$-tocopherol $9.4 \%$ and $10.1 \%$, respectively. The between-run CVs for $\alpha$-carotene, $\beta$-carotene, $\beta$-cryptoxanthin, lycopene and lutein were $7.2 \%, 7.5 \%, 12.6 \%, 8.1 \%$ and $8.6 \%$ in plasma and $18.6 \%$, $21.8 \%, 26.4 \% 16.7 \%$ and $19.6 \%$ in adipose tissue samples, respectively.

The concentrations of fatty acids in adipose tissue were determined using gas-liquid chromatography as described by Lillington et al. ${ }^{17}$. Briefly, approximately $2 \mathrm{mg}$ of adipose tissue biopsy were collected and kept in 
hexane-isopropanol (3:2) mixture. A $200 \mu$ l quantity of this mixture was taken and methanol and acetyl chloride added to form methyl esters. After esterification, the adipose tissue was evaporated, and the fatty acid methyl esters re-dissolved in iso-octane and then quantified by gas-liquid chromatography. Conditions employed were as follows: fused silica capillary cis/trans column SP2560, $100 \mathrm{~m} \times 250 \mu \mathrm{m}$ i.d. $\times 20 \mu \mathrm{m}$ film (Supelco, Belefonte, PA); split-less injection port at $240^{\circ} \mathrm{C}$; hydrogen carrier gas at $1.3 \mathrm{ml} / \mathrm{min}$, constant flow; Hewlett-Packard (now Agilent) model GC 6890 FID gas chromatograph with 7673 Autosampler injector (Palo Alto, CA); $1 \mu \mathrm{l}$ of sample injected; temperature programme of 90 to $170^{\circ} \mathrm{C}$ at $10^{\circ} \mathrm{C} \mathrm{min}^{-1}, 170^{\circ} \mathrm{C}$ for $5 \mathrm{~min}, 170$ to $175^{\circ} \mathrm{C}$ at $5^{\circ} \mathrm{C} \mathrm{min}^{-1}$, 175 to $185^{\circ} \mathrm{C}$ at $2^{\circ} \mathrm{C} \mathrm{min}^{-1}, 185$ to $190^{\circ} \mathrm{C}$ at $1^{\circ} \mathrm{C} \mathrm{min}^{-1}, 190$ to 210 at $5^{\circ} \mathrm{C} \mathrm{min}^{-1}, 210^{\circ} \mathrm{C}$ for $5 \mathrm{~min}, 210$ to $250^{\circ} \mathrm{C}$ at

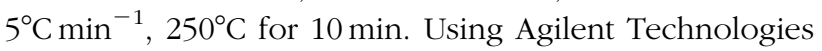
ChemStation A.08.03 software for analysis, peak retention times and area percentage of total fatty acids were identified after injecting known standards (NuCheck Prep, Elysium, MN). The CVs for 16 blind duplicates of lauric, myristic, palmitic, palmitoleic, stearic, arachidic, oleic, eicosenoic, linoleic, linolenic, arachidonic, eicosapentaenoic, docosapentaenoic and docosahexaenoic acids included with the unknown samples were 35.6\%, 24.9\%, 5.4\%, 14.0\%, 16.0\%, 14.3\%, 3.0\%, 11.3\%, 5.5\%, 8.5\%, 11.2\%, $19.8 \%, 12.1 \%$ and $15.1 \%$, respectively.

Plasma triacylglycerol, cholesterol and high-density lipoprotein cholesterol concentrations were measured using enzymatic reagents (Boehringer-Mannheim, Indianapolis, IN) and a Roche Cobas Mira Plus Autoanalyzer. The Centers for Disease Control and the National Heart, Lung and Blood Institute guidelines on cholesterol measurements were used to standardise cholesterol determinations in our laboratory ${ }^{18,19}$.

\section{Statistical analyses}

All data were managed and analysed using the Statistical Analysis Systems software (SAS Institute, Inc., Cary, NC). Variables were checked for outliers and normality, and, where necessary, transformed using the natural logarithm or square-root transformation. Nutrient intakes were adjusted for total energy intake by regressing the transformed variable on total energy intake as described by Willett ${ }^{20}$. Similarly, log-transformed plasma tocopherol concentrations were regressed on plasma triacylglycerol. Adjusting for total plasma cholesterol instead of triacylglycerol gave similar results. The same procedure was used to adjust plasma carotenoids for total cholesterol. All further analysis was done on total energy- or plasma triacylglycerol- or cholesterol-adjusted variables.

Analysis of variance was performed using the GLM procedure in SAS to determine whether dietary intake and plasma and adipose concentrations of major nutrients vary across levels of urbanisation. The significance of the differences between rural, suburban and urban subpopulation means was assessed using the Tukey multiple comparison test.

For categorical variables, the significance of the differences in proportions of subjects in the rural, suburban and urban areas was tested using the chi-square test.

\section{Results}

The major sources of energy in this study population are shown in Fig. 2. Descriptive characteristics of rural, suburban and urban sub-populations in Costa Rica are presented in Table 1. The proportions of males and heavy smokers $\left(>10\right.$ cigarettes day ${ }^{-1}$ ) in rural Costa Rica tended to be higher than in suburban and urban areas, but the differences in the sub-populations were not significant

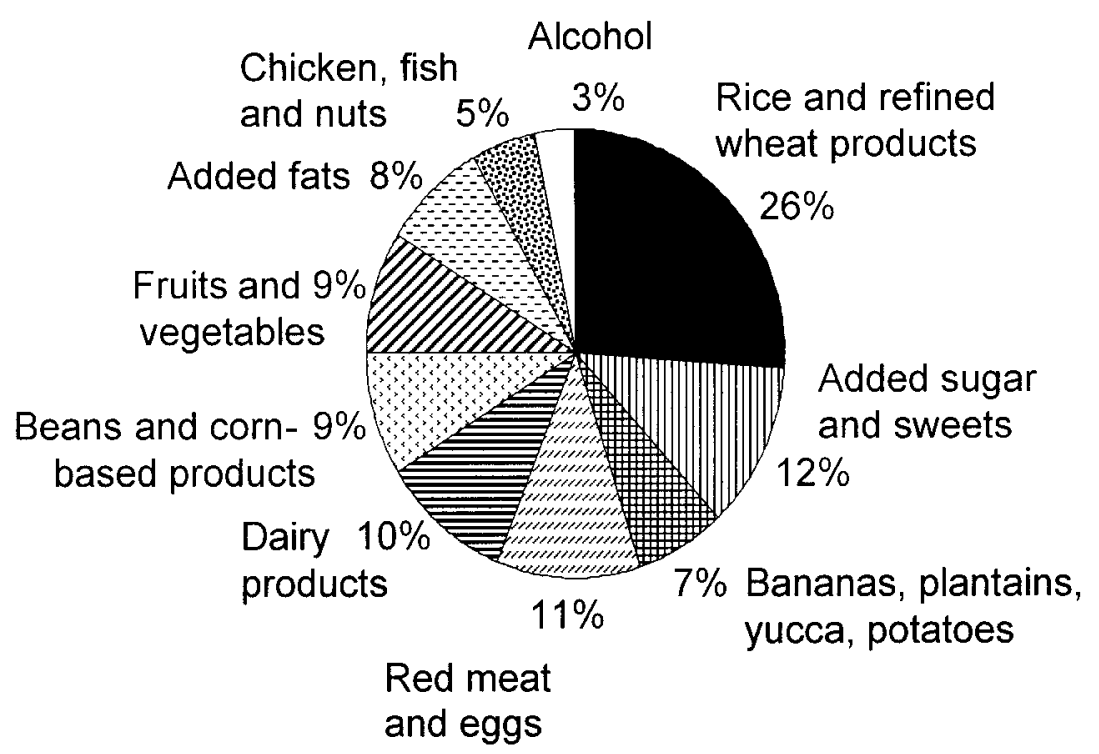

Fig. 2 Main sources of energy for residents of San José metropolitan area and adjacent counties in Costa Rica 
Table 1 Descriptive characteristics of rural, suburban and urban populations in Costa Rica

\begin{tabular}{|c|c|c|c|}
\hline \multirow[b]{2}{*}{ Variable } & \multicolumn{3}{|c|}{ Percentage or mean $\pm \mathrm{SD}^{*}$} \\
\hline & $\begin{array}{c}\text { Rural } \\
(n=77)\end{array}$ & $\begin{array}{c}\text { Suburban } \\
(n=140)\end{array}$ & $\begin{array}{c}\text { Urban } \\
(n=286)\end{array}$ \\
\hline Age (years) & $58.5 \pm 11$ & $56.3 \pm 11$ & $56.9 \pm 11$ \\
\hline Males in the population $(\%) \dagger$ & 81.8 & 75.7 & 69.2 \\
\hline Body mass index $\left(\mathrm{kg} \mathrm{m}^{-2}\right)$ & $26.3 \pm 4.5$ & $25.5 \pm 4.2$ & $26.0 \pm 3.9$ \\
\hline Waist-to-hip ratio & $0.96 \pm 0.08^{\mathrm{a}}$ & $0.94 \pm 0.07^{\mathrm{ab}}$ & $0.93 \pm 0.07^{b}$ \\
\hline Physical activity (METS) & $2.3 \pm 1.4^{\mathrm{a}}$ & $1.8 \pm 0.8^{\mathrm{b}}$ & $1.7 \pm 0.8^{\mathrm{b}}$ \\
\hline Monthly household income (US\$) & $384.5 \pm 368^{\mathrm{a}}$ & $498.8 \pm 428^{a}$ & $648.9 \pm 531^{\mathrm{b}}$ \\
\hline \multicolumn{4}{|l|}{ Smoking status $(\%) \dagger$} \\
\hline Never smoked & 29.9 & 35.7 & 38.3 \\
\hline Past smokers & 40.3 & 37.9 & 35.8 \\
\hline Current smokers $\left(<10\right.$ cigarettes day $\left.{ }^{-1}\right)$ & 11.7 & 12.1 & 13.7 \\
\hline Current smokers ( $>10$ cigarettes day ${ }^{-1}$ ) & 18.2 & 14.3 & 12.3 \\
\hline History of diabetes $(\%) \dagger$ & 14.3 & 15.0 & 9.1 \\
\hline History of hypertension (\%)† & 26.0 & 25.0 & 27.3 \\
\hline History of angina $(\%) \dagger$ & 1.3 & 0.7 & 0.7 \\
\hline History of angina - Rose questionnaire $(\%) \dagger$ & 2.6 & 6.4 & 3.2 \\
\hline \multicolumn{4}{|l|}{ Plasma } \\
\hline Total cholesterol $\left(\mathrm{mg} \mathrm{dl}^{-1}\right)$ & $201.1 \pm 38$ & $196.6 \pm 38$ & $203.0 \pm 39$ \\
\hline HDL cholesterol $\left(\mathrm{mg} \mathrm{dl}^{-1}\right)$ & $40.8 \pm 12^{\mathrm{ab}}$ & $40.0 \pm 12^{\mathrm{a}}$ & $42.8 \pm 11^{\mathrm{b}}$ \\
\hline LDL cholesterol ( $\left.\mathrm{mg} \mathrm{dl}^{-1}\right)^{\prime}$ & $119.6 \pm 32$ & $117.0 \pm 37$ & $121.2 \pm 35$ \\
\hline Triacylglycerol $\left(\mathrm{mg} \mathrm{dl}^{-1}\right)$ & $212.5 \pm 101$ & $208.9 \pm 119$ & $207.7 \pm 116$ \\
\hline
\end{tabular}

SD - standard deviation; HDL - high-density lipoprotein; LDL - low-density lipoprotein.

* Means with dissimilar row superscripts are significantly different, $P<0.05$, the rest are not.

$\dagger \chi^{2} P>0.05$

Table 2 Comparison of total energy-adjusted macronutrient intakes and type of cooking oil used in rural, suburban and urban populations in Costa Rica

\begin{tabular}{|c|c|c|c|}
\hline \multirow[b]{2}{*}{ Variable } & \multicolumn{3}{|c|}{ Percentage or mean $\pm \mathrm{SD}^{*}$} \\
\hline & $\begin{array}{l}\text { Rural } \\
(n=77)\end{array}$ & $\begin{array}{c}\text { Suburban } \\
(n=140)\end{array}$ & $\begin{array}{c}\text { Urban } \\
(n=286)\end{array}$ \\
\hline Total energy (kcal day ${ }^{-1}$ ) & $2392 \pm 855$ & $2310 \pm 675$ & $2302 \pm 657$ \\
\hline Protein $\left(\mathrm{g} \mathrm{day}^{-1}\right)$ & $75.2 \pm 12$ & $75.5 \pm 14$ & $75.2 \pm 15$ \\
\hline Total fat ( g day $\left.^{-1}\right)$ & $79.2 \pm 15^{\mathrm{a}}$ & $80.4 \pm 15^{a}$ & $84.6 \pm 16^{b}$ \\
\hline Saturated fat $\left(\mathrm{g} \mathrm{day}^{-1}\right)$ & $28.9 \pm 7.0$ & $28.4 \pm 7.4$ & $29.0 \pm 6.3$ \\
\hline MUFA ( g day $^{-1}$ ) & $28.9 \pm 7.6^{\mathrm{a}}$ & $29.4 \pm 6.9^{\mathrm{a}}$ & $32.1 \pm 9.7^{b}$ \\
\hline$n-3$ PUFA (g day $\left.{ }^{-1}\right)$ & $0.35 \pm 0.22^{\mathrm{a}}$ & $0.41 \pm 0.24^{\mathrm{ab}}$ & $0.44 \pm 0.26^{b}$ \\
\hline$n-6$ PUFA $\left(\mathrm{g} \mathrm{day}^{-1}\right)$ & $11.6 \pm 3.2^{\mathrm{a}}$ & $12.5 \pm 3.7^{\mathrm{ab}}$ & $13.0 \pm 3.7^{\mathrm{b}}$ \\
\hline Trans-fatty acids $\left(\mathrm{g} \mathrm{day}^{-1}\right)$ & $3.50 \pm 1.80^{\mathrm{a}}$ & $3.86 \pm 1.76^{\mathrm{ab}}$ & $4.17 \pm 1.87^{\mathrm{b}}$ \\
\hline Total carbohydrate $\left(\right.$ g day $\left.^{-1}\right)$ & $304.6 \pm 49$ & $305.7 \pm 47$ & $297.3 \pm 49$ \\
\hline Dietary fibre ( $\mathrm{g} \mathrm{day}^{-1}$ ) & $25.8 \pm 6.0^{\mathrm{a}}$ & $24.4 \pm 6.5^{\mathrm{ab}}$ & $23.1 \pm 6.5^{\mathrm{b}}$ \\
\hline Cholesterol ( mg day $\left.^{-1}\right)$ & $317.1 \pm 209$ & $270.8 \pm 126$ & $270.7 \pm 127$ \\
\hline Use of multivitamins $(\%) \dagger$ & 2.6 & 5.7 & 8.8 \\
\hline Folic acid $\left(\mu\right.$ g day $\left.^{-1}\right) \ddagger$ & $367.8 \pm 77$ & $348.8 \pm 74$ & $344.3 \pm 87$ \\
\hline Vitamin $\mathrm{B}_{6}\left(\mathrm{mg} \mathrm{day}^{-1}\right) \ddagger$ & $2.36 \pm 0.59$ & $2.23 \pm 0.55$ & $2.20 \pm 0.55$ \\
\hline Vitamin $B_{12}\left(\mu\right.$ g day $\left.^{-1}\right) \ddagger$ & $5.60 \pm 3.71$ & $5.73 \pm 3.76$ & $5.51 \pm 3.58$ \\
\hline Vitamin $\mathrm{C}\left(\mathrm{mg} \mathrm{day}^{-1}\right) \ddagger$ & $245.3 \pm 98$ & $224.4 \pm 92$ & $233.9 \pm 110.8$ \\
\hline Vitamin $\mathrm{K}\left(\mu \mathrm{g}_{\text {day }}{ }^{-1}\right) \ddagger$ & $88.2 \pm 58$ & $85.5 \pm 62$ & $96.8 \pm 76$ \\
\hline Iron $\left(\right.$ mg day $\left.^{-1}\right) \ddagger$ & $14.6 \pm 2.3$ & $14.8 \pm 2.4$ & $14.2 \pm 2.2$ \\
\hline Calcium $\left(\mathrm{mg} \mathrm{day}^{-1}\right) \ddagger$ & $854.7 \pm 266$ & $802.6 \pm 256$ & $824.3 \pm 283$ \\
\hline Alcohol $\left(\mathrm{g} \mathrm{day}^{-1}\right) \S$ & $21.2 \pm 26$ & $16.5 \pm 24$ & $13.7 \pm 18$ \\
\hline \multicolumn{4}{|l|}{ Type of cooking oil (\%) } \\
\hline Palm & 52.0 & 40.0 & 30.0 \\
\hline Soyabean & 40.3 & 47.9 & 52.8 \\
\hline Other & 7.8 & 12.1 & 17.3 \\
\hline
\end{tabular}

SD - standard deviation; MUFA - monounsaturated fatty acids; PUFA - polyunsaturated fatty acids.

${ }^{*}$ Means with dissimilar row superscripts are significantly different, $P<0.05$, the rest are not.

$\dagger \chi^{2} P>0.05$

$\ddagger$ Excludes intake from supplements.

$\S$ Means computed only from 230 subjects who consumed alcohol.

I $\chi^{2} P<0.05$. 
$(P>0.05)$. Subjects in the rural areas were significantly $(P<0.05)$ more active physically, earned less income and had a higher intake of dietary fibre than urban dwellers (Tables 1 and 2).

Urban dwellers reported a significantly $(P<0.05)$ higher consumption of total fat, monounsaturated fat, $n-3$ and $n-6$ polyunsaturated fatty acids (PUFA) and trans-fat than those in rural areas. It is notable that use of palm oil for cooking or frying is reported more in rural than in urban or suburban areas, while use of soyabean oil is more common $(P<0.05)$ among suburban and urban populations (Table 2 ). There were no significant $(P>0.05)$ differences in age, body mass index (BMI), plasma triacylglycerol and plasma total and low-density lipoprotein (LDL) cholesterol concentrations (Table 1). Also, there were no significant $(P>0.05)$ differences in dietary intakes of total energy, protein, saturated fat, carbohydrates, iron, calcium, alcohol, folic acid and vitamins $\mathrm{B}_{6}, \mathrm{~B}_{12}$, $\mathrm{C}$ and $\mathrm{K}$ (Table 2).

Differences in carotenoid, tocopherol and fatty acid intakes across levels of urbanisation and by dietary assessment method are presented in Tables 3 and 4 . The intakes of $\alpha$-tocopherol, lycopene and oleic, linoleic and all-trans $18: 1$ fatty acids were significantly $(P<0.05)$ higher among urban dwellers than in rural populations. Although mean dietary intakes of most carotenoids, tocopherols and fatty acids tended to be higher among urban inhabitants, the differences between the subpopulations were not statistically significant $(P>0.05)$.

Plasma mean concentrations of $\alpha$-tocopherol, $\gamma$ tocopherol, $\beta$-cryptoxanthin and lycopene were significantly higher $(P<0.05)$ among urban than rural populations (Table 3). For $\alpha$-tocopherol and lycopene, the mean differences between suburban and urban populations were also significant $(P<0.05)$. There were no significant $(P>0.05)$ differences observed between plasma $\alpha$-carotene, $\beta$-carotene and zeaxanthin/lutein concentrations among the three sub-populations.

Mean adipose tissue concentrations of $\gamma$-tocopherol, lycopene, linoleic, all-trans 18:1 and all-trans 18:2 fatty acids were significantly higher $(P<0.05)$ in urban than in rural populations (Tables 3 and 4 ). Adipose tissue palmitic acid and docosahexaenoic acid concentrations were significantly lower $(P<0.05)$ in urban than in rural populations. The mean differences observed for other adipose tissue carotenoids, tocopherols and fatty acids were not significant $(P>0.05)$ (Tables 3 and 4 ).

\section{Discussion}

Dietary intakes of micro- and macronutrients across levels of urbanisation in Costa Rica were assessed in this study. In addition, information on some known CVD risk factors was collected and the rural, suburban and urban subpopulations described with regard to these factors. This study is of importance in that it does augment previous 
Table 4 Comparison of fatty acid intakes in rural, suburban and urban populations in Costa Rica

\begin{tabular}{|c|c|c|c|c|c|c|}
\hline \multirow[b]{2}{*}{ Nutrient } & \multicolumn{3}{|c|}{ FFQ $\left(\text { g day }^{-1}\right)^{*} \dagger$} & \multicolumn{3}{|c|}{ Adipose tissue $(\% \text { of total adipose tissue fat })^{*} \dagger$} \\
\hline & $\begin{array}{l}\text { Rural } \\
(n=77)\end{array}$ & $\begin{array}{c}\text { Suburban } \\
(n=140)\end{array}$ & $\begin{array}{l}\text { Urban } \\
(n=286)\end{array}$ & $\begin{array}{l}\text { Rural } \\
(n=77)\end{array}$ & $\begin{array}{c}\text { Suburban } \\
(n=140)\end{array}$ & $\begin{array}{l}\text { Urban } \\
(n=286)\end{array}$ \\
\hline \multicolumn{7}{|l|}{ Saturated fatty acids } \\
\hline Lauric acid (12:0) & $0.39 \pm 0.32^{a}$ & $0.47 \pm 0.43^{a b}$ & $0.49 \pm 0.37^{b}$ & $0.02 \pm 0.02$ & $0.02 \pm 0.03$ & $0.02 \pm 0.03$ \\
\hline Myristic acid (14:0) & $1.67 \pm 0.84$ & $1.68 \pm 0.85$ & $1.79 \pm 0.81$ & $1.00 \pm 0.40$ & $1.01 \pm 0.45$ & $1.00 \pm 0.44$ \\
\hline Palmitic acid (16:0) & $19.77 \pm 4.4$ & $19.14 \pm 4.48$ & $19.27 \pm 3.90$ & $22.38 \pm 2.67^{\mathrm{a}}$ & $21.66 \pm 2.61^{\mathrm{ab}}$ & $21.36 \pm 2.67^{b}$ \\
\hline Stearic acid (18:0) & $5.63 \pm 1.34$ & $5.74 \pm 1.59$ & $5.92 \pm 1.46$ & $3.03 \pm 1.03$ & $2.87 \pm 0.96$ & $3.00 \pm 0.92$ \\
\hline Arachidic acid (20:0) & $0.007 \pm 0.003$ & $0.007 \pm 0.004$ & $0.007 \pm 0.004$ & $0.18 \pm 0.09$ & $0.19 \pm 0.12$ & $0.19 \pm 0.09$ \\
\hline \multicolumn{7}{|l|}{ Monosaturated fatty acids } \\
\hline Palmitoleic acid (16:1) & $1.29 \pm 0.41$ & $1.28 \pm 0.45$ & $1.33 \pm 0.46$ & $6.42 \pm 2.11$ & $6.45 \pm 2.12$ & $6.06 \pm 2.00$ \\
\hline Oleic acid (18:1) & $26.84 \pm 7.32^{\mathrm{a}}$ & $27.27 \pm 6.50^{\mathrm{a}}$ & $29.90 \pm 9.47^{b}$ & $44.59 \pm 2.38$ & $44.49 \pm 2.67$ & $44.11 \pm 2.87$ \\
\hline Eicosenoic acid (20:1) & $0.16 \pm 0.07$ & $0.16 \pm 0.07$ & $0.18 \pm 0.12$ & $0.12 \pm 0.11$ & $0.11 \pm 0.09$ & $0.11 \pm 0.09$ \\
\hline \multicolumn{7}{|l|}{ Polysaturated fatty acids } \\
\hline Linoleic acid (18:2) & $11.28 \pm 3.15^{\mathrm{a}}$ & $12.21 \pm 3.65^{\mathrm{ab}}$ & $12.69 \pm 3.68^{b}$ & $12.44 \pm 3.02^{\mathrm{a}}$ & $13.07 \pm 3.23^{\mathrm{ab}}$ & $13.77 \pm 3.25^{\mathrm{b}}$ \\
\hline Linolenic acid (18:3) & $1.17 \pm 0.25$ & $1.20 \pm 0.27$ & $1.25 \pm 0.33$ & $0.52 \pm 0.14$ & $0.54 \pm 0.16$ & $0.55 \pm 0.16$ \\
\hline Arachidonic acid (20:4) & $0.09 \pm 0.07$ & $0.08 \pm 0.04$ & $0.08 \pm 0.04$ & $0.44 \pm 0.14$ & $0.43 \pm 0.13$ & $0.44 \pm 0.13$ \\
\hline Eicosapentaenoic acid (20:5)‡ & $0.04 \pm 0.05$ & $0.04 \pm 0.04$ & $0.05 \pm 0.07$ & $0.04 \pm 0.02$ & $0.04 \pm 0.02$ & $0.04 \pm 0.02$ \\
\hline Docosapentaenoic acid (22:5)‡ & $0.01 \pm 0.01$ & $0.02 \pm 0.01$ & $0.02 \pm 0.02$ & $0.21 \pm 0.05$ & $0.20 \pm 0.06$ & $0.21 \pm 0.06$ \\
\hline Docosahexaenoic acid (22:6) & $0.10 \pm 0.08$ & $0.12 \pm 0.10$ & $0.14 \pm 0.14$ & $0.19 \pm 0.06^{\mathrm{a}}$ & $0.16 \pm 0.06^{\mathrm{a}}$ & $0.17 \pm 0.06^{b}$ \\
\hline \multicolumn{7}{|l|}{ Trans-fatty acids } \\
\hline $14: 1 n-5 t \ddagger$ & $0.002 \pm 0.01$ & $0.006 \pm 0.02$ & $0.006 \pm 0.02$ & $0.019 \pm 0.02$ & $0.019 \pm 0.02$ & $0.018 \pm 0.02$ \\
\hline $16: 1 n-7 t \neq$ & $0.002 \pm 0.01$ & $0.004 \pm 0.01$ & $0.004 \pm 0.01$ & $0.071 \pm 0.03$ & $0.082 \pm 0.03$ & $0.083 \pm 0.03$ \\
\hline All-trans 18:1 & $2.04 \pm 1.06^{\mathrm{a}}$ & $2.31 \pm 1.07^{\mathrm{ab}}$ & $2.56 \pm 1.28^{\mathrm{b}}$ & $1.46 \pm 0.57^{\mathrm{a}}$ & $1.64 \pm 0.56^{\mathrm{b}}$ & $1.80 \pm 0.61^{\mathrm{c}}$ \\
\hline All-trans 18:2 & $1.22 \pm 0.90$ & $1.35 \pm 0.91$ & $1.41 \pm 0.82$ & $1.13 \pm 0.43^{a}$ & $1.30 \pm 0.51^{\mathrm{b}}$ & $1.36 \pm 0.49^{b}$ \\
\hline
\end{tabular}

FFQ - food-frequency questionnaire.

${ }^{*}$ Within each dietary assessment method, means with dissimilar row superscripts are significantly different, $P<0.05$, the rest are not.

† Assessments from FFQ are adjusted for total energy intake while those from adipose tissue are adjusted for the area of the chromatogram.

$\ddagger$ Skewed and therefore not adjusted for total energy intake.

studies on dietary intakes and CVD risk factors across levels of urbanisation in Costa Rica ${ }^{18,21,22}$. It is interesting to note that for the three sub-populations studied, BMI and plasma total and LDL cholesterol are not significantly different $(P>0.05)$ despite the differences in total dietary fat, trans-fat and cholesterol intakes. High cholesterol intake in the rural population could have been negated by the high physical activity and high intake of dietary fibre reported in this sub-population. High dietary fibre intake is known to lower plasma total and LDL cholesterol ${ }^{23-26}$. The high physical activity observed in the rural population remained significant $(P<0.05)$ even after controlling for education and level of income (analysis not shown). Leon $^{27}$ has described the beneficial effects of high physical activity and different dietary components in the prevention of coronary atherogenesis.

In the urban sub-population, the high total fat intake observed appears to be mainly polyunsaturated fat from soyabean oil. High soyabean oil use in the urban subpopulation could imply low consumption of other sources of saturated fat and/or cholesterol, resulting in reduced total intake and therefore low plasma cholesterol concentrations. This could be one of the reasons why there were no differences in LDL and total plasma cholesterol concentrations among the three sub-populations. The relatively high proportion of soyabean oil users observed among urban residents could also explain the higher $\alpha$ - and $\gamma$-tocopherol concentrations reported in the urban than in the rural population. Data from our analysis of palm and soyabean oils from Costa Rica show that palm oil is not only lower in total unsaturated fatty acids, especially the polyunsaturated ones, but also in total tocopherol content. The proportions of saturated, monounsaturated, polyunsaturated and trans-fatty acids in palm oil were 49.7\%, 39.0\%, $9.6 \%$ and $1.7 \%$, respectively, while soyabean oil had $15.4 \%, 26.0 \%, 32.7 \%$ and $26.0 \%$, respectively. The amounts of $\alpha$ - and $\gamma$-tocopherol in $100 \mathrm{~g}$ of palm oil were $2132 \mu \mathrm{g}$ and $213 \mu \mathrm{g}$, respectively, while they were $1385 \mu \mathrm{g}$ and $5539 \mu \mathrm{g}$, respectively, in $100 \mathrm{~g}$ of soyabean oil ( $\mathrm{H}$. Campos, unpublished results, 2000). In the urban subpopulation, soyabean oil is preferred to palm oil, probably as an indicator of socio-economic status, and this could also explain the high $(P<0.05)$ dietary intake of $n-3$ and $n-6$ PUFA reported by urban relative to rural residents. Unsaturated fats, e.g. long-chain $n-3$ fatty acids, have been shown to lower the risk of CVD such as stroke ${ }^{28,29}$. Consumption of palm oil is very common in Costa Rica ${ }^{22}$ and could possibly account for most of the fat intake observed in rural areas. Unfortunately, palm oil is high in saturated fat, poor in total unsaturated fatty acids and total tocopherol, but is the principal source of vitamin $\mathrm{E}^{22}$ probably because of its high usage especially in rural areas. Compared with palm oil, soyabean oil is rich in trans-fatty acids. This could account for the significantly high amounts of dietary and adipose tissue trans-fatty 
acids detected in the urban compared with the rural population.

Unlike total fat intake, which was highest in the urban group, the highest intake of dietary fibre was observed in the rural population. The mean daily intake of dietary fibre observed in this study $\left(23.1-25.8 \mathrm{~g} \mathrm{day}^{-1}\right)$ is similar to that reported in Costa Rica $\left(20.3 \mathrm{~g} \mathrm{day}^{-1}\right.$ ) by Aráuz et $a{ }^{21}{ }^{21}$. According to Rodríguez-Herrera et $a l^{22}$, most of the dietary fibre in the Costa Rican diet comes from beans. Also, beans have a high folic acid content and contributed $20 \%$ of the total folic acid and $24 \%$ of the total fibre intake in our study (data not shown). Our data show that intake of beans was significantly higher $(P<0.05)$ in the rural sub-population $\left(2-3\right.$ times day $\left.^{-1}\right)$ than in the suburban and urban sub-populations (1 time day $\left.{ }^{-1}\right)$. Individuals who ate beans $2-3$ times day $^{-1}$ had a mean folic acid intake of $384 \mu \mathrm{g} \mathrm{day}^{-1}$, compared with $316 \mu \mathrm{g} \mathrm{day}^{-1}$ for those who ate beans $<1$ time day ${ }^{-1}$. Interestingly, high intake of beans was significantly $(P<0.05)$ associated with low income, suggesting that this excellent source of folic acid and fibre is affordable by the majority of the population. We did not see a difference in the intake of saturated fatty acids in the three sub-populations, but observed high physical activity and high cholesterol and fibre intakes in the rural population. Also, we did not observe significant differences in plasma LDL cholesterol in the three sub-populations despite high total fat intake and sedentary activity in urban areas. These findings could indicate that, although there are major differences in dietary intakes and level of physical activity, the three subpopulations might not be different with regard to their risk of atherogenesis. This observation is of interest because various studies, especially in the metropolitan area of San José, have described Costa Rican diets as atherogenic ${ }^{21,22}$.

The proportion of Costa Rican residents who tended to use multivitamins was greater in urban areas (8.8\%) than in suburban (5.7\%) and rural (2.6\%) areas. We did not observe significant $(P>0.05)$ differences in mean intakes of folic acid, calcium, iron and vitamins $\mathrm{B}_{6}, \mathrm{~B}_{12}, \mathrm{C}$ and $\mathrm{K}$ across the three sub-populations. The intakes observed in this study need to be examined further against recommended daily nutrient allowances, so as to improve the current national nutritional educational programmes in Costa Rica.

\section{Conclusions}

These data show differences in CVD risk factors of rural and urban populations in Costa Rica. In rural areas, low socio-economic status, low intake of unsaturated fats and high intake of cholesterol appear to be the prevalent known CVD risk factors, while in urban areas they were low physical activity, high trans-fatty acids in the diet and adipose tissue, and low dietary fibre intake.

\section{Acknowledgements}

The co-operation of the subjects in this study is highly appreciated. The authors thank the fieldworkers of Proyecto Salud Coronaria, San José, Costa Rica, for their help in data collection. This work was supported by research grant HL 49086 from the National Institutes of Health.

\section{References}

1 Campos H, Lopez-Miranda J, Rodriguez C, Albajar M, Schaefer EJ, Ordovas JM. Urbanization elicits a more atherogenic lipoprotein profile in carriers of the apolipoprotein A-IV-2 allele than in A-IV-1 homozygotes. Arterioscler. Thromb. Vasc. Biol. 1997; 17: 1074-81.

2 Dominguez LJ, Barbagallo M, Sowers JR. Cardiovascular risk factors in South America and the Caribbean. Ethn. Dis. 1999; 9: $468-78$.

3 Singh RB, Suh IL, Singh VP, Chaithiraphan S, Laothavorn P, Sy RG, et al. Hypertension and stroke in Asia: prevalence, control and strategies in developing countries for prevention. J. Hum. Hypertens. 2000; 14: 749-63.

4 Anderson JW, Hanna TJ, Peng XJ, Kryscio RJ. Whole grain foods and heart disease risk. J. Am. Coll. Nutr. 2000; 19: 291S-9S.

5 Anon. Self-reported physical inactivity by degree of urbanization - United States, 1996. MMWR Morb. Mortal. Wkly. Rep. 1998; 47(50): 1097-100.

6 Wilcox S, Castro C, King AC, Housemann R, Brownson RC. Determinants of leisure time physical activity in rural compared with urban older and ethnically diverse women in the United States. J. Epidemiol. Community Health 2000; 54: $667-72$.

7 Morgan K, Armstrong GK, Huppert FA, Brayne C, Solomou W. Healthy ageing in urban and rural Britain: a comparison of exercise and diet. Age Ageing 2000; 29: 341-8.

8 Campos H, Mata L, Siles X, Vives M, Ordovas JM, Schaefer EJ. Prevalence of cardiovascular risk factors in rural and urban Costa Rica. Circulation 1992; 85: 648-58.

9 Hall C. Costa Rica. A Geographical Interpretation in Historical Perspective. Dellplain Latin American Studies No. 17. Boulder, CO: Westview Press, 1985.

10 Anon. Report of the expert committee on the diagnosis and classification of diabetes mellitus. Diabetes Care 1998; 21: S5-22.

11 Rose GA, Blackburn H, Gillum RF, Prineas RJ. Cardiovascular Survey Methods, 2nd ed. World Health Organization (WHO) Monograph Series No. 56. Geneva: WHO, 1982.

12 Willett WC, Sampson L, Stampfer MJ, Rosner B, Bain C, Witschi $\mathrm{J}$, et al. Reproducibility and validity of a semiquantitative food frequency questionnaire. Am. J. Epidemiol. 1985; 122: 51-65.

13 Campos H, Willett WC, Peterson RM, Siles X, Bailey SM, Wilson PW, et al. Nutrient intake comparisons between Framingham and rural and urban Puriscal, Costa Rica. Associations with lipoproteins, apolipoproteins, and low density lipoprotein particle size. Arterioscler. Thromb. 1991; 11: 1089-99.

14 Kabagambe EK, Baylin A, Allan DA, Siles X, Spiegelman D, Campos H. Application of the method of triads to evaluate the performance of food frequency questionnaires and biomarkers as indicators of long-term dietary intake. $\mathrm{Am}$. J. Epidemiol. 2001; 154: 1126-35.

15 Beynen AC, Katan MB. Rapid sampling and long-term storage of subcutaneous adipose-tissue biopsies for 
determination of fatty acid composition. Am. J. Clin. Nutr 1985; 42: 317-22.

16 Hess D, Keller HE, Oberlin B, Bonfanti R, Schuep W. Simultaneous determination of retinol, tocopherols, carotenes and lycopene in plasma by means of highperformance liquid chromatography on reversed phase. Int J. Vitam. Nutr. Res. 1991; 61: 232-8.

17 Lillington JM, Trafford DJ, Makin HL. A rapid and simple method for the esterification of fatty acids and steroid carboxylic acids prior to gas-liquid chromatography. Clin Chim. Acta 1981; 111: 91-8.

18 Myers GL, Kimberly MM, Waymack PP, Smith SJ, Cooper GR, Sampson EJ. A reference method laboratory network for cholesterol: a model for standardization and improvement of clinical laboratory measurements. Clin. Chem. 2000; 46: $1762-72$.

19 Myers GL, Cooper GR, Winn CL, Smith SJ. The Centers for Disease Control-National Heart, Lung and Blood Institute Lipid Standardization Program. An approach to accurate and precise lipid measurements. Clin. Lab. Med. 1989; 9: 105-35.

20 Willett W. Nutritional Epidemiology, 2nd ed. Monographs in Epidemiology and Biostatistics. New York: Oxford University Press, 1988.

21 Aráuz AG, Monge RA, Munoz L, Rojas MT. Diet as a risk factor for cardiovascular disease in residents of the metropolitan area, San Jose, Costa Rica. Arch. Latinoam. Nutr. 1991; 41: 350-62.
22 Rodríguez HN, Gladys AA, Meza RN, Rosello AM Atherogenic factors in the diet of the Costa Rican population, 1991. Arch. Latinoam. Nutr. 1996; 46: 27-32.

23 Ullrich IH. Evaluation of a high-fiber diet in hyperlipidemia: a review. J. Am. Coll. Nutr. 1987; 6: 19-25.

24 Jenkins DJ, Kendall CW, Mehling CC, Parker T, Rao AV, Agarwal S, et al. Combined effect of vegetable protein (soy) and soluble fiber added to a standard cholesterol-lowering diet. Metabolism 1999; 48: 809-16.

25 Vidal-Quintanar RL, Mendívil RL, Peña M, Fernandez ML Lime-treated maize husks lower plasma LDL-cholesterol levels in normal and hypercholesterolaemic adult men from northern Mexico. Br. J. Nutr. 1999; 81: 281-8.

26 Brown L, Rosner B, Willett W, Sacks FM. Cholesterollowering effects of dietary fiber: a meta-analysis. Am.J. Clin. Nutr. 1999; 69: 30-42.

27 Leon AS. Physiological interactions between diet and exercise in the etiology and prevention of ischaemic heart disease. Ann. Clin. Res. 1988; 20: 114-20.

28 Pedersen JI, Ringstad J, Almendingen K, Haugen TS, Stensvold I, Thelle DS. Adipose tissue fatty acids and risk of myocardial infarction - a case-control study. Eur. J. Clin. Nutr. 2000; 54: 618-25.

29 Iso H, Rexrode KM, Stampfer MJ, Manson JE, Colditz GA, Speizer FE, et al. Intake of fish and omega-3 fatty acids and risk of stroke in women. J. Am. Med. Assoc. 2001; 285 $304-12$. 